ГОТОВНІСТЬ МАЙБУТНІХ БАКАЛАВРІВ 3 ФІЗИЧНОЇ ТЕРАПІЇ, ЕРГОТЕРАПІЇ ДО ЗАСТОСУВАННЯ ФІЗКУЛЬТУРНО-ОЗДОРОВЧИХ ТЕХНОЛОГІЙ У ПРОФЕСІЙНІЙ ДІЯЛЬНОСТІ ЗА МОТИВАЦІЙНО-ЦІННІСНИМ КОМПОНЕНТОМ

\title{
THE READINESS OF FUTURE BACHELORS OF PHYSICAL THERAPY, ERGOTHERAPY FOR THE APPLICATION OF RECREATIONAL TECHNOLOGIES IN THE PROFESSIONAL ACTIVITY UNDER THE MOTIVATIONAL AND VALUABLE COMPONENT
}

УДК 378.147:[615.825+615.851.3]-051 DOI https://doi.org/10.32843/2663$6085 / 2020 / 22-4.24$

\section{Беспалова 0.0.,}

старший викладач кафедри здоров'я, фрізичної терапії, реабілітації

та ерготерапії

Сумського державного педагогічного університету імені А.С. Макаренка Лянной ю.О.,

докт. пед. наук, просресор, ректор Сумського державного педагогічного університету імені А.С. Макаренка Бугаєнко Т.В., канд. пед. наук,

старший викладач кафедри здоров'я, фрізичної терапії, реабілітації

та ерготерапії

Сумського державного педагогічного університету імені А.С. Макаренка Лянна О.В.,

канд. пед. наук,

старший викладач кафедри здоров'я фрізичної терапії, реабілітації та ерготерапії

Сумського державного педагогічного університету імені А.С. Макаренка
Просресійна діяльність фрізичного терапевта спрямована на максимально можливе відновлення втрачених або послаблених фуункцій організму людини, отриманих внаслідок травм та захворювань. 3 огляду на те, що фізкультурно-оздоровчі технології $\epsilon$ обов'язковим компонентом програм фрізичної реабілітації (терапіі)), нині завдання постає у визначенні методик форомування готовності майбутніх бакалаврів з фрізичної терапії, ерготерапії до їх застосування у майбутній профресійній діяльності, виборі діагностичного інструментарію, що дасть змогу відстежувати динаміку їі форорування за окремими компонентами. У структурі зазначеної готовності виділяємо мотиваційно-ціннісний, суб'єктний, когнітивно-змістовий та діяльнісний компоненти. 3 урахуванням того, що внутрішня мотивація $\epsilon$ підгрунтям для усвідомленого глибокого засвоєння фрахових знань важливим залишається питання визначення ефективності запропонованих методів організації навчальної діяльності майбутніх бакалаврів з фрізичної терапії, ерготерапії та рівень ссоормованості їх готовності до застосування фрізкультурно-оздоровчих технологій у професійній діяльності за мотиваційноціннісним компонентом. Застосування відповідного діагностичного інструментарію (методика вибору профеесії, методика мотивації до успіху T. Елерса) дала нам змогу вивчити рівень сформованості готовності за чим компонентом. За результатами емпіричного дослідження був виявлений недостатній рівень сфоормованості мотиваційно-ціннісного компонента. Для посилення мотивації студентів спеціальності «Фізична терапія, ерготерапія» розроблена та впроваджена методична система впливу на ї формування, яка передбачала впровадження сучасних освітніх технологій навчання (проблемні та проєктні методи, інтерактивні технологіі). Отримані результати дають підстави стверджувати, що мотиваційна сфрера студентів експериментальної групи наприкінці формувального експерименту $\epsilon$ більш сприятливою з точки зору формування готовності до застосування фрізкультурно-оздоровчих технологій, ніж у контрольній групі студентів.
Ключові слова: фрахівці з фрізичної терапії, ерготерапії, готовність, мотивація, цінності, компоненти, критерії, показники, рівні ссрормованості готовності.

The professional activity of a physical therapist is aimed at maximizing the restoration of the lost or weakened functions of the human body resulting from injuries and diseases. Taking into account that physical and recreational technologies are an obligatory component of programs of physical rehabilitation (therapy), today appears in determining the methods of forming the readiness of future bachelors in physical therapy, ergotherapy for their use in future professional activity, the choice of diagnostic toolkit, which will allow molding by individual components. In the structure of determined readiness we distinguish motivational-value, subjective, cognitive-content and activity components. Given that intrinsic motivation is the basis for conscious deep mastering of professional knowledge, the question remains to determine the effectiveness of the proposed methods of organizing educational activities of future bachelors in physical therapy, ergotherapy to the level of formation of their readiness for the use of physical education and technology, whose criterion was the motivational criterion. Applying the appropriate diagnostic tools (the technique of choosing a profession, the method of motivation for T. Ehlers' success) allowed us to study the level of readiness generated by this component According to the results of empirical research, insufficient level of motivational-value component formation was revealed. To enhance the motivation of students of the specialty "Physical therapy, ergotherapy" a methodological system of influence on its formation was developed and implemented, which included the introduction of modern educational technologies of teaching (problem and design methods, interactive technologies). The results obtained suggest that the motivational sphere of the students of the experimental group at the end of the forming experiment is more favorable in terms of forming readiness for the use of fitness and health technologies than in the control group of students. Key words: specialists in physical therapy, ergotherapy, readiness, motivation, values, components, criteria, indicators, levels of readiness.
Постановка проблеми у загальному вигляді. Вимоги Міністерства охорони здоров'я та потреби суспільства створюють попит на конкурентоспроможного фрахівця, який здатен до безперервного професійного самовдосконалення та срахової мобільності у напрямі застосування сучасних засобів реабілітації, серед яких головне місце посідають фрізкультурно-оздоровчі технології. Це зумовлює потребу у визначенні методик фрормування готовності майбутніх бакалаврів 3 фрізичної терапії, ерготерапії до застосування фрізкультурнооздоровчих технологій у майбутній професійній діяльності, виборі діагностичного інструментарію, що дасть змогу відстежувати динаміку її фрорму- 
вання за окремими компонентами. 3 огляду на те, що внутрішня мотивація є підґрунтям для усвідомленого глибокого засвоєння фрахових знань важливим залишається питання визначення ефрективності запропонованих методів організації навчальної діяльності майбутніх бакалаврів з фрізичної терапії, ерготерапії та рівень сорормованості їх готовності до застосування фрізкультурнооздоровчих технологій у професійній діяльності за мотиваційно-ціннісним компонентом.

Аналіз останніх досліджень і публікацій. Питаннями сучасних фрізкультурно-оздоровчих технологій займаються Н.Н. Венгерова, М.В. Верховська, А.А. Горелов, В.Л. Кондаков, О.Г. Румба, О.А. Качан, Ю.О. Усачев та ін.

Проблему мотивації людини вивчали Д. Макклелланд, Г. Хекхаузен, Г. Келлі, К. Роджерс, Р. Мей, А.Н. Леонтьєв та ін. Суттєвий науковий внесок щодо педагогічних та психологічних аспектів мотивації був зроблений С.Л. Рубінштейном, Ю.К. Бабанським, В.О. Сухомлинським, Л.І. Божович, С.С. Занюк, Є.М. Ільїним, В.І. Ковальовим, І.П. Подласим та ін.

Виділення не вирішених раніше частин загальної проблеми. У результаті аналізу науково-методичної літератури з'ясовано, що у системі фрормування готовності майбутніх фрахівців 3 фрізичної терапії, ерготерапії відсутні дидактичні і методичні аспекти розвитку мотивації та ціннісного ставлення до професії фрізичного терапевта, ерготерапевта загалом та застосування фрізкультурно-оздоровчих технологій зокрема.

Метою статті $€$ висвітлення результатів експериментального дослідження у напрямі сорормованості готовності майбутніх бакалаврів з фрізичної терапії, ерготерапії до застосування фрізкультурнооздоровчих технологій у професійній діяльності за мотиваційно-ціннісним компонентом.

Методи дослідження: теоретичні: аналіз таузагальнення спеціальної науково-методичної літератури; емпіричні: анкетування - для визначення динаміки зрушень під час фрормування готовності майбутніх бакалаврів з фрізичної терапії та ерготерапії до застосування фрізкультурно-оздоровчих технологій у професійній діяльності; статистичні методи математичної статистики для визначення значущості й вірогідності отриманих результатів.

Виклад основного матеріалу. 3 метою оцінки стану профресійної готовності майбутніх фрахівців 3 фрізичної терапії до застосування фрізкультурно-оздоровчих технологій нами було уточнено поняття «готовність до застосування фрізкультурнооздоровчих технологій» як складне динамічне особистісне утворення, яке забезпечує поточну реалізацію фрізкультурно-оздоровчої профресійної діяльності і полягає у оволодінні спеціальними знаннями фрізкультурно-оздоровчих технологій та вміннями, пов'язаними з ними, прийомами та методами їх використання та передбачає наявність психологічних якостей, необхідних для фрахівця з фрізичної терапії та ерготерапії, є підґрунтям для професійного самовдосконалення. Відповідно, стан готовності до майбутньої профресійної діяльності являє собою складну динамічну систему, яка забезпечується єдністю її компонентів.

Дослідження науковців щодо структури готовності фрахівців до майбутньої профресійної діяльності вказують, що провідним у фрормуванні та розвитку фахових знань, умінь та навичок, особистісних якостей є саме мотиваційно-ціннісний компонент. Цей фракт підтверджується результатами наукових розвідок Ю.О. Лянного, який розглядає мотиваційно-ціннісний компонент як базис фрормування і реалізації інших компонентів у структурі готовності магістрів фрізичної реабілітації, основними характеристиками якого $є$ позитивна мотивація до наукової і професійної діяльності реабілітолога, інтерес до діяльності, усвідомлення їі значущості, розуміння перспектив саморозвитку в профресії [6, с. 136-140].

Мотивація $€$ рушійною силою зовнішньої і внутрішньої активності суб'єкта та посідає провідне місце в структурі особистості [7, с. 104]. У своїх дослідженнях І.С. Войтович підкреслює, що мотивація є регуляторним компонентом навчальної діяльності, який забезпечує високу результативність навчання унаслідок педагогічного впливу та прогнозує пізнавальну активність студентів і перетворює зовнішню регуляцію на саморегуляцію [3, с. 47-59].

У нашому дослідженні мотиваційно-ціннісний компонент характеризується наявністю у студентів системи цінностей, інтересів, потреб і мотивів засвоєння змісту теоретичних та процесуальнометодичних аспектів застосування фрізкультурнооздоровчих технологій у професійній діяльності. Оцінювання рівня сорормованості за цим компонентом здійснювалося за мотиваційним критерієм, показниками якого виступали: рівень сформованості та характер мотивації.

Констатувальним дослідженням були охоплені майбутні фрахівці 4-5 курсів спеціальності «Фізична терапія, ерготерапія (фрізична реабілітація)» Сумського державного педагогічного університету імені А.С. Макаренка, Кам'янець-Подільського національного університету імені Івана Огієнка, Національного університету «Чернігівський колегіум» імені Т.Г. Шевченка, Бердянського державного педагогічного університету та Ужгородського національного університету загальною кількістю 124 студенти.

3 метою виявлення мотивів, які найбільше посприяли вибору професії фрізичного терапевта, ерготерапевта (фрізичного реабілітолога), нами була використана методика «Мотиви вибору професії», де студенти оцінювали рівень впливу 
зазначених тверджень за п'ятибальною шкалою. У результаті з'ясовано, що найбільш значущими мотивами вибору професії фрізичного терапевта та ерготерапевта (фрізичного реабілітолога) стали: відповідність професії індивідуальним здібностям (середня оцінка 4,9 бала); можливість розумового і фрізичного розвитку (середня оцінка 4,9 бала); можливість зростання професійної майстерності (середня оцінка 4,9 бала); можливість реалізувати творчий потенціал у професії (середня оцінка 4,9 бала); привабливість професії (середня оцінка 4,8 бала); престижність (середня оцінка 4,6 бала); достойний рівень оплати праці (середня оцінка 4,6 бала); можливість застосування профресійних умінь поза роботою (середня оцінка 4,6 бала).

Отримані результати вказують на те, що від обраної професії студенти очікують самореалізації в професійному середовищі, можливості кар'єрного зростання і надання якісної професійної допомоги пацієнтам/клієнтам, а також розширення соціальних зв'язків та кола спілкування. Зміст провідних мотивів вказує на усвідомленість вибору цієї профресії та розуміння перспектив подальшого професійного розвитку.

Серед найменш актуальних мотивів зазначена висока відповідальність обраної професії, що вказує на невпевненість майбутніх фрахівців у власній готовності до здійснення професійної діяльності.

Рівень сорормованості та характер мотивації оцінювався за допомогою методики Т. Елерса. Отримані результати дослідження вказують, що більшість досліджуваних (58 осіб, або 46,8\%) виявили низький рівень мотивації успіху. Також значна кількість студентів мають середній рівень мотивації (51 студент, що відповідає 41,1\%) і лише 15 студентів (або 12,1\%) характеризуються високим рівнем мотивації успіху.

Отже, аналіз вищезазначених емпіричних даних зумовлює необхідність посилення мотивації студентів. На нашу думку, перспективним у цьому напрямі $є$ усвідомлення студентами рівня професійної відповідальності фрахівця з фрізичної терапії, ерготерапії, цілеспрямована робота щодо реалізації в процесі навчання професійних і пізнавальних інтересів, актуалізація мотивації успіху в навчально-професійній діяльності.

3 метою оптимізації мотиваційно-ціннісного компонента готовності майбутніх бакалаврів 3 фрізичної терапії та ерготерапії до застосування фрізкультурно-оздоровчих технологій у нашому дослідженні було використано широкий спектр методів навчання: проблемне та проєктне навчання, інтерактивні технології. Для їх упровадження в освітній процес користувалися рекомендаціями та спиралися на досвід сучасних науковців [5; 7-9].

Під час впровадження методів проблемного навчання відбувається інтенсифрікація пізнавальної активності студентів та підвищення моти- ваційного ефректу. Розумові зусилля, спрямовані на пошук способів вирішення проблемного завдання, зумовлюють внутрішню зацікавленість, стають чинником активізації навчального процесу, підвищують ефрективність засвоєння фрізкультурно-оздоровчих технологій. Запропоновані проблемні завдання спонукають студентів до творчого мислення - висунення, обґрунтування і перевірки припущень щодо вирішення проблеми, аналізу отриманих результатів. Виконання завдання має викликати потребу у здобутті раніше невідомих знань або способів дій, розвивати інтерес до навчання [5, с. 120-121].

Базовою дисципліною з огляду на потенційні можливості щодо фрормування готовності фрахівців $з$ фрізичної терапії, ерготерапії до застосування фрізкультурно-оздоровчих технологій у професійній діяльності обрано «Функціональний фітнес». Як інорормаційно-методичний супровід навчального процесу застосовувався розроблений нами навчально-методичний комплекс дисципліни «Функціональний фрітнес», у змісті якого розкрито мету і завдання дисципліни, інфрормаційний обсяг програми, структуру навчальної дисципліни, представлено опорний конспект лекцій, плани практичних занять. Також були розроблені «Методичні рекомендації до практичних занять 3 навчальної дисципліни «Функціональний фрітнес» [1] та «Робочий зошит для практичних занять з навчальної дисципліни «Функціональний фрітнес» [2], в яких викладено детальну структуру практичних занять, яка включає теоретичні запитання, практичні, домашні, індивідуальні науково-дослідні завдання, контрольні питання для оцінювання підсумкових знань студентів. Вказані матеріали були викладені в особистому кабінеті викладача на сайті університету та мали відкритий доступ для студентів відповідної спеціальності, що дало їм змогу зорієнтуватися у змісті дисципліни. Серед електронних засобів навчання нами використовувалися електронні версії підручників, словники, енциклопедії. Це дало змогу студентам зорієнтуватися у змісті та структурі дисциплін. 3 метою діагностики навчальних досягнень студентів використовувалися комп'ютерні засоби (комп'ютерне тестування на базі програмного продукту RegTest). Технічні засоби навчання (мультимедіа, аудіо- та відеоматеріали) сприяли покращенню сприйняття та осмислення програмного матеріалу, а спеціальні програмні продукти (імітаційні й моделюючі тренажери, програми діагностики рухових функцій) стали ефективним засобом стимулювання емоційного сприйняття інорормації та активізації емоційного впливу на заняттях. Для активної комунікації викладача та студентів використовувалися такі засоби комунікації, як електронна пошта, соціальні мережі, месенджери тощо. 
Основними організаційними формами навчальної роботи у процесі формування готовності майбутніх бакалаврів 3 фрізичної терапії та ерготерапії до застосування фрізкультурно-оздоровчих технологій були лекційні та практичні заняття, самостійна робота студентів та практика (ознайомча, за профілем майбутньої профресії, клінічна). Лекційний матеріал створює інфрормаційне забезпечення щодо основних питань змісту навчальної дисципліни. Практичні заняття забезпечують фрормування відповідних профресійних умінь і навичок застосовувати теоретичні знання у процесі планування, розробки і впровадження фрізкультурно-оздоровчих технологій для здійснення різних видів фрахової діяльності. У разі самостійної роботи фоомуються уміння та навички щодо прийняття самостійних усвідомлених рішень та здійснення самостійних дій у випадках, які вимагають вирішення складних навчальних ситуацій. Практика сприяє ознайомленню з наявним практичним досвідом спеціалістів у галузі охорони здоров'я, його аналізу та запозичення, оцінці матеріально-технічної бази лікувальнопрофрілактичного, оздоровчо-реабілітаційного та інших закладів, розвитку продуктивного мислення щодо можливостей їх застосування у роботі із пацієнтами/клієнтами різних нозологічних груп.

У формувальному експерименті взяли участь 180 студентів Кам'янець-Подільського національного університету імені Івана Огієнка, Сумського державного педагогічного університету імені А.С. Макаренка, Національного університету «Чернігівський колегіум» імені Т.Г. Шевченка, Бердянського державного педагогічного університету, Ужгородського національного університету, які були розподілені на експериментальну (92 студенти) та контрольну (88 студентів) групи. В експериментальній групі освітній процес організовувався за розробленою та обґрунтованою нами освітньою методикою фрормування готовності майбутніх бакалаврів з фрізичної терапії та ерготерапії до застосування фрізкультурно-оздоровчих технологій у професійній діяльності. Освітній процес у контрольній групі реалізовувався за усталеними підходами і технологіями.
3 метою перевірки ефективності впровадженої нами методики формування у майбутніх бакалаврів $з$ фізичної терапії та ерготерапії готовності до застосування фрізкультурно-оздоровчих технологій здійснювався аналіз динаміки рівнів ссормованості готовності за мотиваційним критерієм.

Оцінка рівня сорормованості готовності до застосування фрізкультурно-оздоровчих технологій за показником «Рівень сформованості та характер мотивації» мотиваційного критерію відбувалася на основі методики «Мотивація до успіху» Т. Елерса. Узагальнені результати сформованості готовності майбутніх бакалаврів з фрізичної терапії, ерготерапії до застосування фрізкультурно-оздоровчих технологій представлено в таблиці 1 та на рисунку 1.

Таким чином, аналіз результатів формувального дослідження рівня сформованості у майбутніх бакалаврів 3 фрізичної терапії та ерготерапії готовності до застосування фрізкультурно-оздоровчих технологій за показником «Рівень сорормованості та характер мотивації» мотиваційного критерію показав збільшення кількості студентів 3 високим рівнем ссрормованості готовності до застосування фізкультурно-оздоровчих технологій на $21,8 \%$ в експериментальній та на 9\% - у контрольній групі.

Нами зафріксовано збільшення кількості студентів із середнім рівнем сорормованості готовності в експериментальній групі на $14,1 \%$, у контрольній групі - на 12,3\%; кількість бакалаврів 3 низьким рівнем мотиваційної готовності зменшилася в обидвох групах - на 35,9\% в експериментальній та на $14,3 \%$ - у контрольній групі.

Ступінь статистичної значущості відмінностей рівнів ссрормованості готовності до застосування фізкультурно-оздоровчих технологій між експериментальною та контрольною групами студентів визначався з використанням $\chi^{2}$-критерію (критерію К. Пірсона).

На початку фрормувального експерименту між експериментальною та контрольною групами за показником «Рівень ссрормованості та характер мотивації» мотиваційного критерію не існувало значущих відмінностей $\left(X^{2}=0,38\right)$, що свідчить про однорідність досліджуваних груп.

Таблиця 1

Динаміка рівнів сформованості готовності до застосування фрізкультурно-оздоровчих технологій за показником «Рівень сформованості та характер мотивації» мотиваційного критерію

\begin{tabular}{|c|c|c|c|c|c|c|c|c|c|c|}
\hline \multirow{3}{*}{ Рівні } & \multicolumn{5}{|c|}{ Експериментальна група (n=92) } & \multicolumn{5}{|c|}{ Контрольна група (n=88) } \\
\hline & \multicolumn{2}{|c|}{$\begin{array}{c}\text { Початок } \\
\text { експерименту }\end{array}$} & \multicolumn{2}{|c|}{$\begin{array}{c}\text { Кінець } \\
\text { експерименту }\end{array}$} & \multirow{2}{*}{$\begin{array}{c}\text { Різниця, } \\
\%\end{array}$} & \multicolumn{2}{|c|}{$\begin{array}{c}\text { Початок } \\
\text { експерименту }\end{array}$} & \multicolumn{2}{|c|}{$\begin{array}{c}\text { Кінець } \\
\text { експери-менту }\end{array}$} & \multirow{2}{*}{$\begin{array}{c}\text { Різниця } \\
\%\end{array}$} \\
\hline & абс. & $\%$ & абс. & $\%$ & & абс. & $\%$ & абс. & $\%$ & \\
\hline Високий & 7 & 7,6 & 27 & 29,4 & $+21,8$ & 8 & 9 & 15 & 17 & +9 \\
\hline Середній & 39 & 42,4 & 52 & 56,5 & $+14,1$ & 35 & 40 & 46 & 52,3 & $+12,3$ \\
\hline Низький & 46 & 50 & 13 & 14,1 & $-5,9$ & 45 & 51 & 27 & 30,7 & $-14,3$ \\
\hline
\end{tabular}




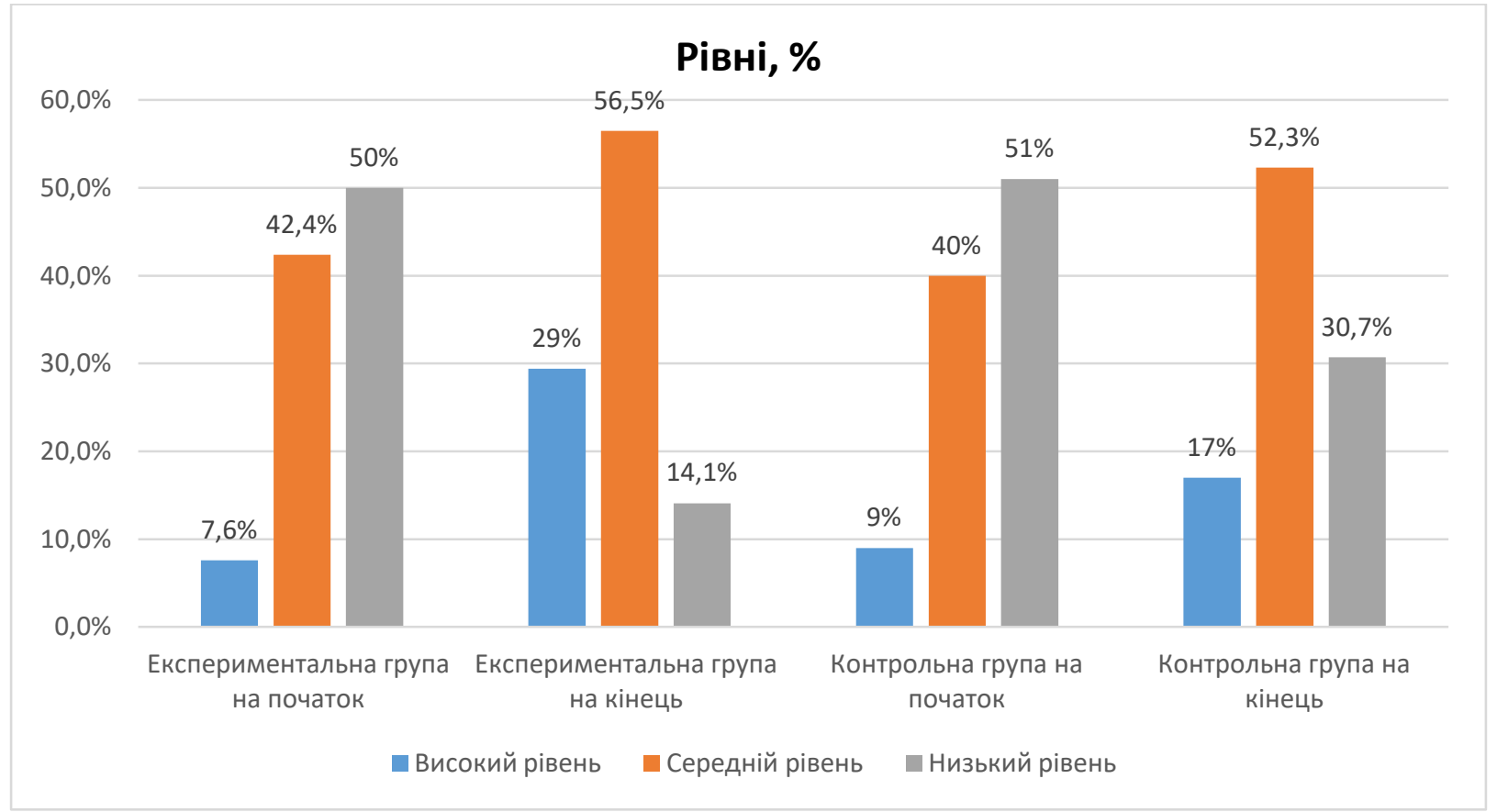

Рис. 1. Динаміка рівнів сформованості готовності до застосування фрізкультурно-оздоровчих технологій за показником «Рівень сформованості та характер мотивації» мотиваційного критерію, \%

Після проведення формувального дослідження значення показника мотиваційного критерію в експериментальній і контрольній групах значно відрізняються $\left(\chi^{2}=18,36\right)$ на рівні значущості $\rho=0,05$.

Засріксована в результаті експерименту більш позитивна динаміка сфрормованості мотиваційної готовності майбутніх бакалаврів з фрізичної терапії та ерготерапії до застосування фрізкультурно-оздоровчих технологій у експериментальній групі, на нашу думку, пов'язана з упровадженням в освітній процес інноваційних технологій навчання, спрямованих на активізацію пізнавальної діяльності і самостійності студентів, уможливлення реалізації індивідуальних інтересів, потенційних творчих можливостей, самореалізації студентів у навчально-професійній діяльності.

Висновки. Готовність до застосування фрізкультурно-оздоровчих технологій - це складне динамічне особистісне утворення, яке забезпечує поточну реалізацію фрізкультурно-оздоровчої просресійної діяльності і полягає у оволодінні спеціальними знаннями фрізкультурно-оздоровчих технологій та вміннями, пов'язаними з ними, прийомами та методами їх використання та передбачає наявність психологічних якостей, необхідних для фрахівця 3 фрізичної терапії та ерготерапії, $€$ підґрунтям для професійного самовдосконалення. У структурі зазначеної готовності виділяємо мотиваційно-ціннісний, суб'єктний, когнітивно-змістовий та діяльнісний компоненти. 3 огляду на те, що мотивація є регулятором навчальної діяльності та впливає наїї продуктивність мотиваційно-ціннісний компонент був визначений як провідний. Застосування відповідного діагностичного інструментарію (методика вибору професії, методика мотивації до успіху Т. Елерса) дав нам змогу вивчити рівень ссрормованості готовності за цим компонентом. Результати емпіричного дослідження вказують на недостатній рівень сорормованості мотиваційноціннісного компонента. Для посилення мотивації студентів спеціальності «Фізична терапія, ерготерапія» розроблена та впроваджена методична система впливу на їі соомування, яка передбачала впровадження сучасних освітніх технологій навчання (проблемних та проєктних методів, інтерактивних технологій). Отримані результати дають підстави стверджувати, що мотиваційна сорера студентів експериментальної групи наприкінці фрормувального експерименту є більш сприятливою з точки зору формування готовності до застосування фрізкультурно-оздоровчих технологій, ніж у контрольній групі студентів. 


\section{БІБЛІОГРАФІЧНИЙ СПИСОК:}

1. Беспалова О.О. Робочий зошит для практичних занять 3 навчальної дисципліни «Функціональний фрітнес». Суми, 2018. 63 с.

2. Беспалова О.О. Методичні рекомендації до практичних занять 3 навчальної дисципліни «Функціональний фрітнес». Суми, 2019. 64 с.

3. Войтович І.С. Мотивація навчання майбутніх учителів у процесі їх підготовки до професійної діяльності. Наукові записки. Серія: Педагогіка, 2014. № 4. С. 47-59.

4. Курлянд3.Н.Педагогікавищоїшколи.Київ.2007.

5. Курнишев Ю.А. Педагогічні умови професійного саморозвитку майбутніх учителів фрізичної культури : дис. ... канд. пед. наук. Київ. 2017. 249 с.

6. Лянной Ю.О. Теоретичні і методичні засади професійної підготовки майбутніх магістрів з фрізич- ної реабілітації у вищих навчальних закладах : дис. ... докт. пед. наук. Київ, 2017. 663 с.

7. Нечипоренко М. Мотивація як ключовий фрактор майбутніх учителів іноземних мов до професійно особистісного саморозвитку. Наукові записки. Серія: Педагогіка, 2017. № 2. С. 102-109.

8. Нікітіна І.Н. Формування професійної мотивації студента як детермінанти його творчого розвитку і працевлаштування / І.Н. Нікітіна, В.В. Мартич. ВІСНИК НТУУ-КПІ. Філософрія. Психологія. Педагогіка, 2010. Випуск 1. С. 206-211.

9. Тригуб І.П. Мотивація студентів як один 3 основних фракторів успішної профресійної підготовки. Наукові записки Національного університету «Острозька академія : збірник наукових праць, 2014. Випуск 48. С. 318-321. 